\title{
Morphology and Histology of Male Reproductive System of Gryllus campestris Linnaeus, 1758 (Orthoptera: Gryllidae)
}

\author{
Gülay GÖKÇE BAYRAM*, Selami CANDAN
}

Gazi University, Faculty of Science, Biology, Ankara, Turkey ORCID ID: Gülay GÖKÇE BAYRAM: https:// orcid.org/0000-0003-3725-6846; Selami CANDAN: https://orcid.org/0000-0002-7402-1360

\begin{abstract}
$\begin{array}{lll}\text { Received: 27.01.2021 Accepted: 25.05.2021 Published online: } 14.06 .2021 & \text { Issue published: } 30.06 .2021\end{array}$
Abstract: The morphological and histological structures of male reproductive system of adult Gryllus campestris Linnaeus,1758 (Orthoptera: Gryllidae) have been defined by using stereo microscope, light microscope, and scanning electron microscope. The male reproductive system of G. campestris is formed as a couple of testes, a pair of vas defence, two seminal vesicles, accessory gland, a single muscular ejaculator bulb and ejaculator duct which opens the aedaegus and spermatophore. The mature G. campestris has two nearly uniformly broad testes. Spermatozoa are produced in the testes. Each testis is formed as series of slender tubules or follicles in which disparate stage of spermatogenesis (spermatocytes, spermatids, and spermatozoa) and spermatozoa develop. Initially, the germ cells at the proximal end of the testicular follicle undergo mitosis to form spermatocytes. Later, spermatids are formed from the spermatocytes in the middle region of the follicles through meiosis. At last, spermatids, the proximal region of the follicle differentiates into spermatozoa. Every follicle is connected to the vas deferens via vas efferens to transfer spermatozoa. Vas efferens is surrounded by a single layer of cubic epithelium containing an oval core. Ejaculatory duct opens and a large ventral male mating organ opens the penis or the end of aedeagus. The accessory glands is a liquid to aid in the transfer during mating female spermatozoa secretes. Spermatophore or sperm ampulla is a capsule or mass containing spermatozoa formed by males. Spermatophore is synthesized by the male accessory glands. Before the sperm is transposed to the female, the spermatophore is located in the sac like the ampulla. In this study, the morphology and histology of the male reproductive system of G. campestris, which is an economically important species for our country, was examined and illustrated by stereo microscope, light microscope and scanning electron microscope (SEM). Our findings, characterizing the structure of the male reproductive system of G. campestris, form the basis of future studies including technological approaches to control this pest in agriculture.
\end{abstract}

Keywords: Testes, vas deferens, spermatogenesis, spermatophore, electron, light and stereo microscopy.

\section{Gryllus campestris Linnaeus, 1758 (Orthoptera: Gryllidae)' in Erkek Üreme Sisteminin Histolojisi ve Morfolojisi}

\begin{abstract}
Öz: Ergin Gryllus campestris Linnaeus,1758 (Orthoptera: Gryllidae)'ın erkek üreme sisteminin histolojik ve morfolojik yapısı stereo mikroskobu, 1şık mikroskobu ve taramalı elektron mikroskobu ile tanımlandı. Erkek üreme sistemi bir çift testis, bir çift vas deferens, iki seminal kese, yardımcı bezler ve kaslı bir ejakulatör kese, aedeagusa açılan bir ejakulatör kanal ve spermatofordan meydana gelmektedir. Olgun G. campestris erkek bireyleri spermatozoa oluşturan bir çift testise sahiptir. Her testis çeşitli spermatogenez aşamalarına (spermatosit, spermatid, spermatozoa) sahip bir dizi ince silindir tübüller veya folikülden oluşur. İlk olarak spermatositler foliküllerin proksimal uçlarında germ hücrelerinin mitoz bölünmesi ile oluşur. Ardından foliküllerin orta bölgesinde mayoz bölünme ile spermatidler meydana gelir. Son olarak foliküllerin proksimal bölgesinde spermatidler spermatozoaya farklılaşır. Her folikül spermatozoayı aktarmak için vas eferens aracılığı ile vas deferense bağlanır. Vas eferens, tek katlı kübik epitel ile çevrilidir ve oval çekirdeklidir. Ejakulator kanal ventralde genişleyerek erkek üreme organı penis veya aedeagusa açılır. Yardımcı bezler çiftleşme sırasında spermatozoanın dişiye aktarılmasına yardımcı olan bir sıvı salgılar. Spermatofor, erkek bireylerin yardımcı bezleri tarafından sentezlenen, spermatozoanın kapsül veya kitle halinde aktarılmasını sağlayan yapılardır. Spermler dişiye akatarılmadan önce bir kese şeklinde spermatofor içinde bulunur. Bu çalışmada ülkemiz için ekonomik açıdan önemli bir tür olan G. campestris erkek üreme sisteminin morfolojisi ve histolojisi stereo mikroskop, 1şık mikroskobu ve taramalı elektron mikroskobu (SEM) ile incelenmiş ve gösterilmiştir. G. campestris'in erkek üreme sisteminin yapısını karakterize eden bulgularımız, tarımda bu zararlıyı kontrol etmek için teknolojik yaklaşımlar da dahil olmak üzere gelecekteki çalışmaların temelini oluşturacaktır.
\end{abstract}

Anahtar kelimeler: Testis, vas deferens, spermatogenez, spermatofor, elektron, 1şık ve stereo mikroskop.

\section{Introduction}

Represented by approximately 26000 species in the world, the Orthoptera order has a wide place among insect orders (Çıplak \& Demirsoy, 1996; Çıplak, et. al., 2002; Demirsoy et.al., 2002; Gullan \& Cranston, 2010). Orthoptera such as katydids are a range of insects that include grasshoppers and crickets, including closely related insects. The order is divided into two subgroups as Caelifera (grasshopper, Locust) and Ensifera (cricket, katydids) (Harz, 1969). G. campestris is a species of crickets and is found in the field cricket genus and the Gryllini tribe. This deep colorful insects that can not fly is relatively wide; the males in range of 19 to $23 \mathrm{~mm}$. The females of this group range in size from 17 to $22 \mathrm{~mm}$. Gryllus is one of the most widespread genus of field crickets. It is found throughout the Americas, Europe and Africa, extending eastwards into tropical Asia (Harz, 1969; Otte \& Cade, 1984; Vrenozi \& Uchman, 2020). 
The male reproductive system in insects includes a couple of testes, a couple of sperm channel (vas deferens) coming out of the testes, an ejaculator channel where the vas deferens are opened, and accessory glands opening to the ejaculator channel. (Viscuso et al., 1999, 2014; Liu et al., 2005; Jones et al., 2013). The structure of the testes follicles of male insects can be used to explain taxonomic relationships. In Orthoptera, the testes are made up of 300400 a thin, tubular follicle, in which spermatogenesis occurs, standing together thanks to the connective tissue. Every follicle is attached to a vas deferens with a very thin vas efferens. (Liu et al., 2005; Jones et al., 2013). In many insect species, spermatozoa are isolated to the genital tract of females by spermatofores with hard and elastic sheath produced by male reproductive acessory glands and transferred in bundles in bulk. (Viscuso \& Vitale, 2015). In insects, there are sperm channels that allow spermatozoa to be transported from the testes. The length of the sperm channel varies between species. Each sperm channel is disunited into two ways, one intratesticular channel and the other vas deferens. Vas deferens is the part of the sperm duct outside the testes. (Viscuso et al., 2014). In some insect species, the part of the sperm canal expands to the point where the ejaculator opens into the canal to collect and store sperm before mating. This structure is the seminal sac with mesodermal origin. In some insect groups such as Trichoptera, there is no seminal sac (Viscuso et al., 1999, 2014). The sperm canal and seminal sacs produce secretion. Here, the male gametes will survive until they are sent to the female (Viscuso et al, 2014). The structure and arrangement of the accessory glands can vary in the same family, subfamily, and even in the same breed. This change in the biochemical structure of the outbreak is associated with different functions in the secretions of the glands, such as sperm cell feeding, suppressing the female's acceptance of other insects, or stimulating the laying of eggs (Marchini et al., 2009). G. campestris is a species of biological and economical importance both in our country and in the world. This study is important in terms of both providing biological control against this species and contributing to the work to be done later.

\section{Material and Methods}

\subsection{Collection and care of experimentals}

The adult male individuals of G. campestris $(n=30)$ were collected from the Kazan, Ankara between June and August 2016. Ten specimens of G. campestris were knocked out by the ethyl acetate vapor and broken into pieces 0,1 $\mathrm{M}$ sodium phosphate tampon, pH 7.2 analyzed. Finally, samples were photographed under the Leica SZX7 stereo microscope (SM).

\subsection{Preparation of samples for light microscopy}

To examine male reproductive system samples histologically, mature samples of the species were fixed in $10 \%$ neutral formalin liquid for 24 hours. The samples were then cleaned in tap water and passed through a series of $50 \%$ to $100 \%$ ethanol to remove their water. Next they were cleaned with xylene, filtrated and buried in paraffin wax $\left(65^{\circ} \mathrm{C}\right)$. Using the Microm HM 310 microtome, 5-6 $\mu \mathrm{m}$ thick sections were taken from these paraffin blocks. The sections colored with hematoxylin and eosin (H\&E) were imaged under the Olympus BX51 LM brand light microscope (LM).

\subsection{Preparation of Samples for Scanning Electron Microscopy}

Samples were fixed in $2.5 \%$ glutaraldehyde $(\mathrm{pH} 7.2$, phosphate buffer) for examination under scanning electron microscopy. Then they washed out three times in phosphate tampon, dried by following up an ethanol progressive series (50, 70, 80, 90 and 100\%). The texture were dried by Hexamethyldisilazane (HMDS). After, the tissues were attached to by double sided tape on the SEM stubs. Then it was covered with gold by spraying gold with the Polaron SC 502 device. Stubs were studied with a JEOL JSM 6060 LV SEM at an acceleration voltage of 5-10 $\mathrm{kV}$. Finally, digital pictures were taken.

\section{Results}

The adult male reproductive system in G. campestris Linnaeus, 1758 is consisted of a pair of whitish, nearly uniformly broad testes, a couple of long vas deferens, seminal vesicles, an ejaculator duct, spermatophore, accessory glands, and aedeagus (Fig. 1 a-d). Each testis consists about 140 follicles which are almost spindle shaped. (Fig. 2 a-b). Testicular follicles have three different developmental zones: growth zone, maturation zone, and differentiation zone. Spermatocytes were observed in the growth zone. (Fig. $3 a-b)$. The growth zone is followed by the maturation zone and spermatids are formed at this stage. (Fig. 4 a-d). In the differentiation zone, spermatids turn into spermatozoa with prominent head, neck and tail parts (Fig 5 a-d). The testes are surrounded with a white peritoneal lamina. The testes are attached to the seminal vesicle via a pair of vas deferens (Fig. 6 a-f). The outer surface of the testicle is inverted with a dense muscle and trachea network. The cells have a monolayer cubic epithelium. Vas deferens is surrounded by an outer muscle layer and sperm bundles were found inside the lumen (Fig. 6 a-f).

At the end of the seminal vesicles accessory glands were observed. Accesory glands consist of a large number of thin long fingerlike structures. The outer surfaces are quite flat and they have a single-layered cubic epithelium (Fig. 7 a-d). The nuclei of the cells are large and in the midst of the cell. Granules were seen in epithelial cells. Lumen is full of secretion (Fig. 7 a-d). Ejaculator canal consists of a single layer cylindrical epithelial cell and muscle layer surrounding ejaculatory duct. Ejaculator canal has muscle bundle. Ejaculator canal opens into the genital chamber (Fig. 8 a-d)

Except those, the spermatophore structure was observed. The spermatophore was fixed at the level of the female gonophore. They are completely made up of the secretion of the male accessory glands. The spermatophore was flask-shaped with a wider part called ampulla with a neck and attachement plate and with a long sperm tube. The sperm is contained within the sac like ampulla of the spermatophore before it is removed to the female (Fig. 9 ad).

\section{Discussion}

The reproductive organ in the insect usually consists of vas deferens, seminal vesicle, ejaculatory duct, and accessory glands; however, some differences can be seen among insect orders. There is morphological diversity in different families in Orthoptera (Snodgrass, 1957). In orthoptera, 
generally have as per the number, shape and organizing of sperm tubules (Snodgrass, 1937). The male reproductive systems of $G$. campestris as other Gryllidae species, generally, consist of a couple of testes, vas deferens, and accessory glands. Male reproductive system of $G$. campestris is consists of two whitish, nearly uniformed
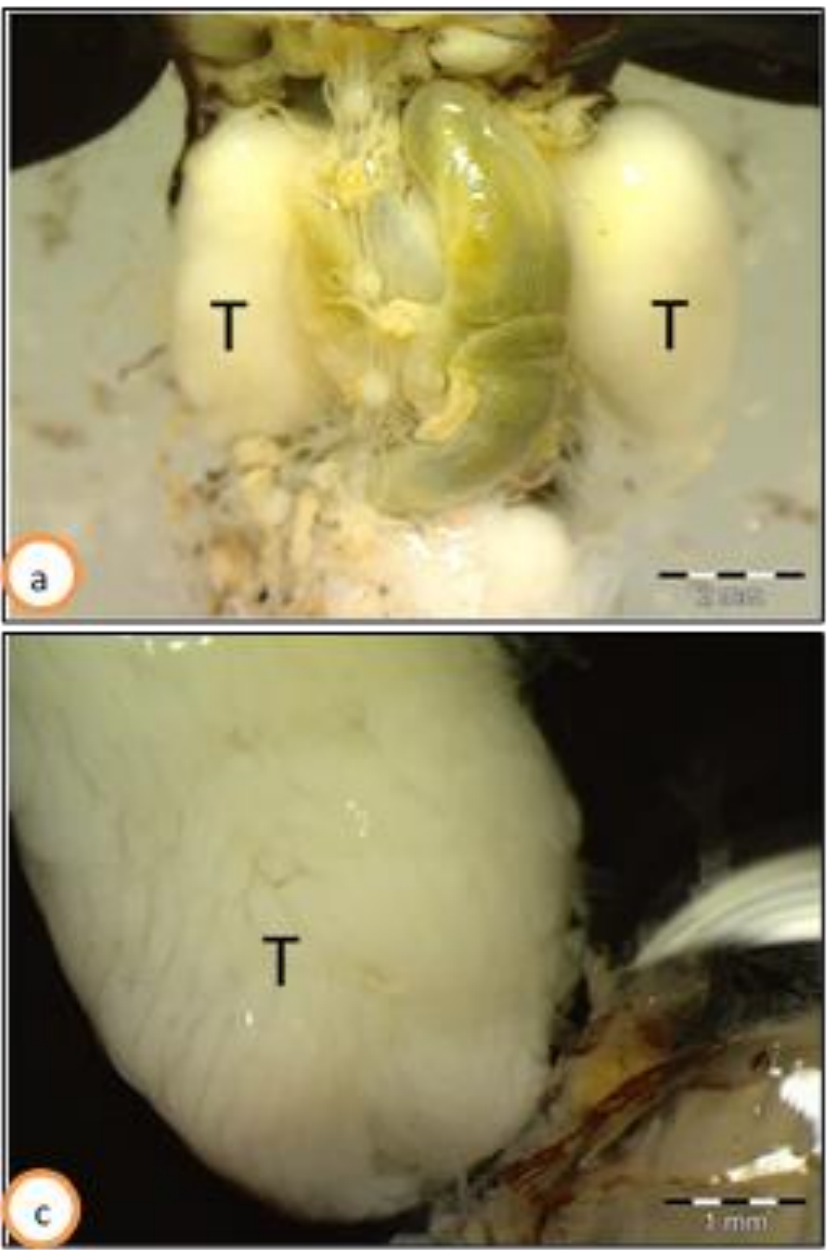

broad testes. Similarly, male reproductive system of Gryllodes sigillatus (Orthoptera: Gryllidae) consists of the testes that are large, white, reversed pear-like organs. Both tests are lying dorso-lateral to the alimentary canal (Nandchahal, 1972).
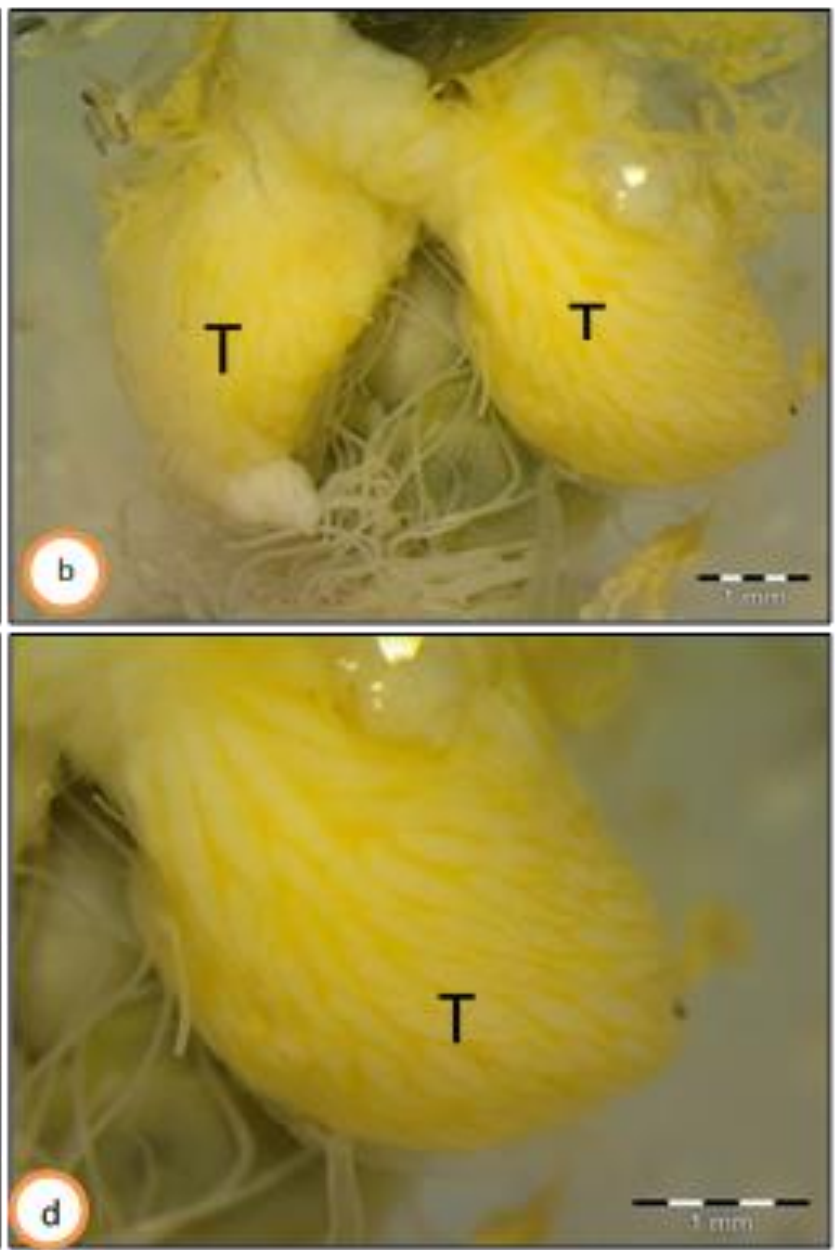

Figure 1. Dissected general morphology of immature and mature male reproductive organs of G. campestris (SM). a. The general view of white colored testis $(\mathrm{T})$ in the immature male reproductive system. b. The general view of yellow colored testis $(\mathrm{T})$ in the mature male reproductive system. c. The testis follicles under the sheath covering the testicle in an immature male. $\mathrm{d}$. The testicular follicles under the sheath covering the testicle in the adult insect.
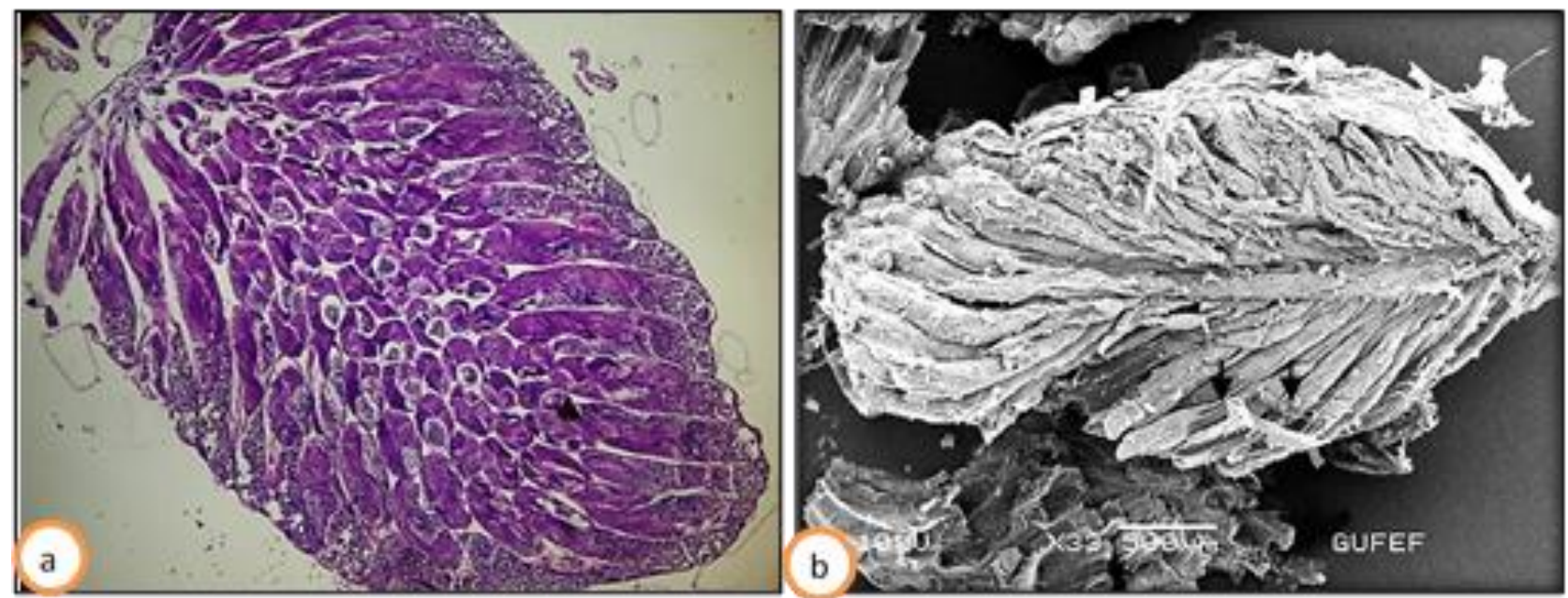

Figure 2. The general view of testis follicles in G. campestris. a. Stages of spermatogenesis seen in testicular follicles in longitudinal section of mature testis (x100) (H\&E) (LM). b. SEM photograph of the longitudinal section of testis follicles (arrow $\longrightarrow$ ) 

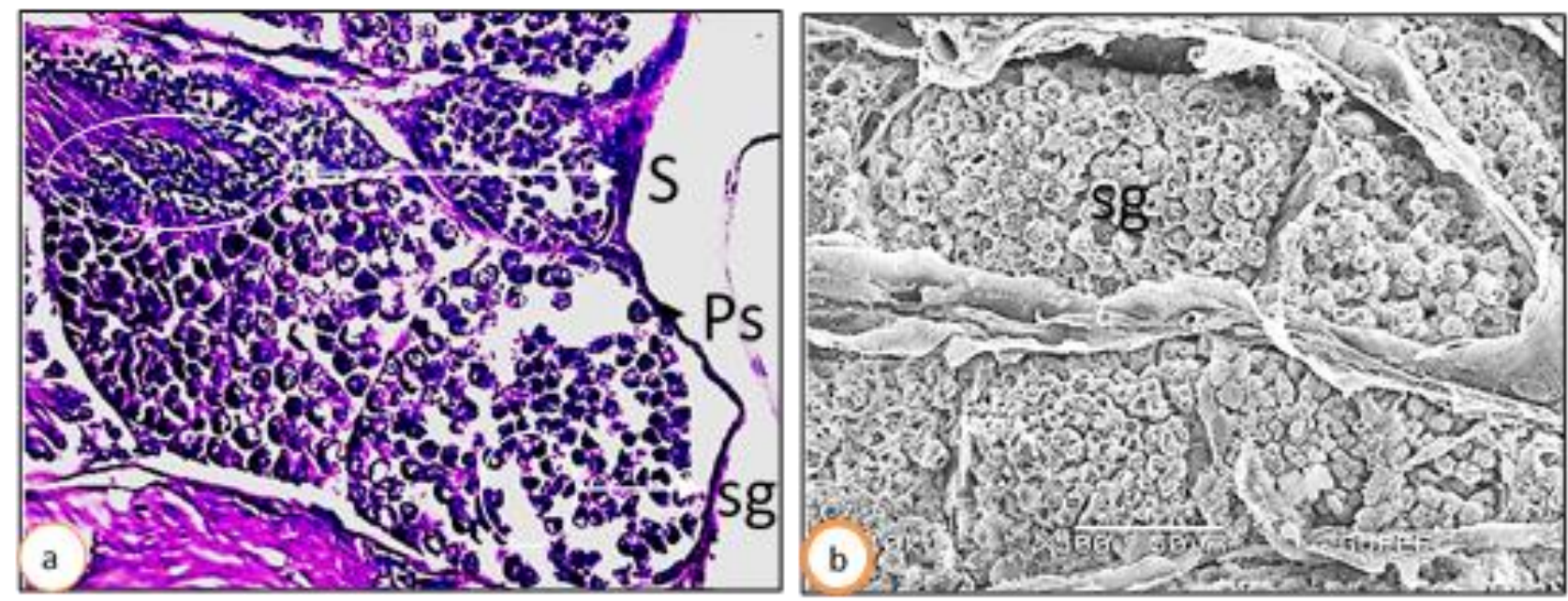

Figure 3. a. Spermatogonia (Sg) and spermatocytes (Sp) in the growth zone ( $\times 400, \mathrm{H \& E})(\mathrm{LM})$. b. Peritoneal sheath (Ps) surrounding the testis and spermatogonia in the testis (SEM).
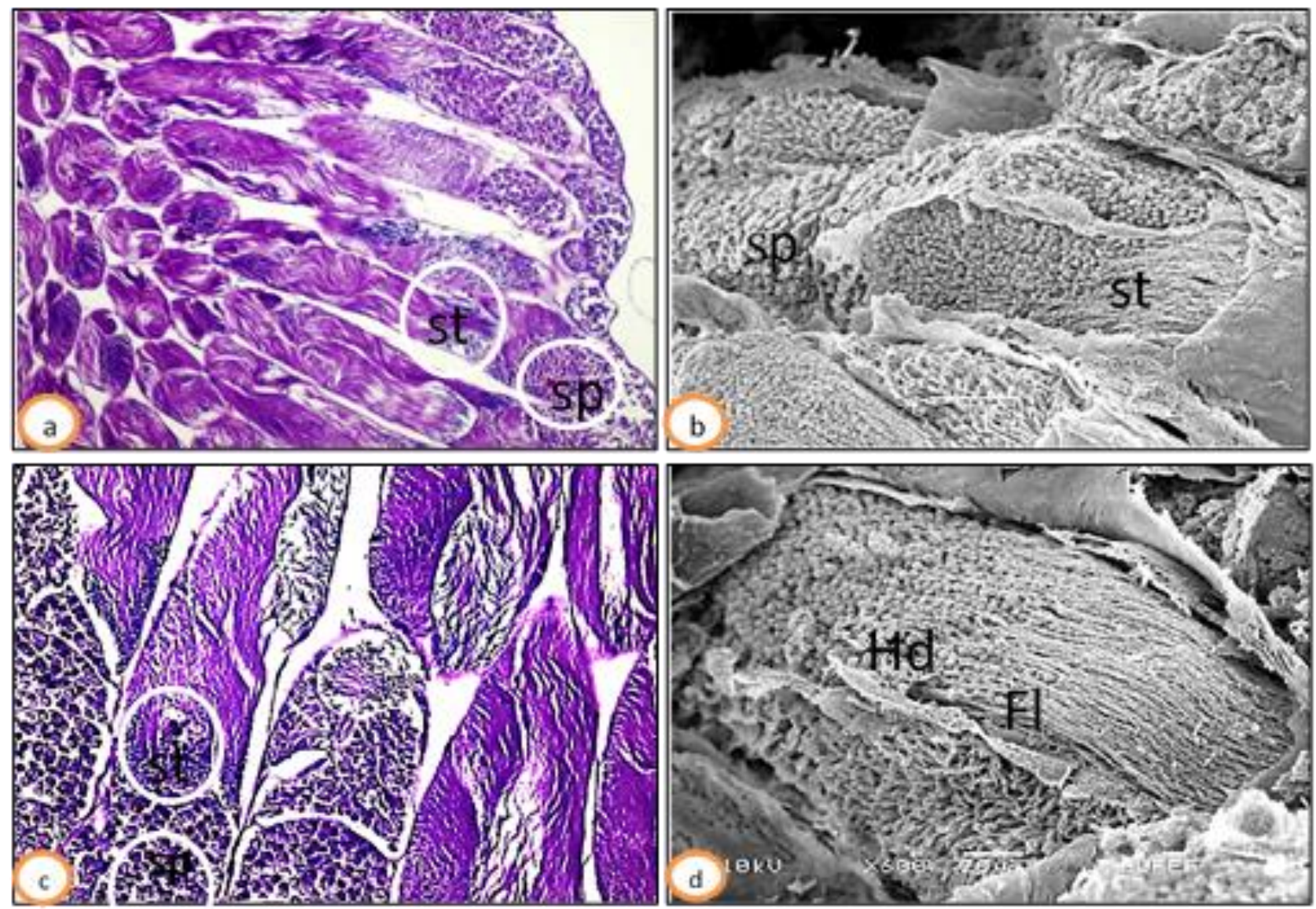

Figure 4. Spermatocytes and spermatids found in the maturation zone of testicular follicles. $a, b$. The transformation of spermatocyte into spermatids in the testicular follicle (x200) (H\&E) (LM and SEM). c. The histological cross-section of spermatocytes (Sp) and spermatids (St) at the maturation zone $(\mathrm{x} 200)(\mathrm{H \& E})(\mathrm{LM})$. d. The flagellum $(\mathrm{Fl})$ and round-shaped head regions (Hd) in spermatids (SEM).

The male reproductive system of Orphulella punctata (Orthoptera: Acrididae) consists of two testes and testicles surrounded by an orange-colored sheath; howewer in Poecilimon cervus (Tettigoniidae) testes are yellow. (Silva et al., 2018; Polat, 2016).

The male genital system of Tetrix arenosa angusta (Hancock) (Orthoptera: Tetrigidae) is consist of the testes, vasa efferentia, vasa deferentia, accessory glands, ejaculatory duct and intromittent organ and a pair of testes of a mature grouse locust. The testicles extend in the hemocoel between the dorsal diaphragm and the alimentary canal (Widdows \&Wick, 1959).

The male reproductive system of Tylopsis liliifolia (Orthoptera: Tettigonidae) composed of a couple of testicles disposed laterally along the alimantary canal. However, male reproductive system of Acrididae testes structure is different. Male reproductive system of Grassopher (Orthoptera: Acrididae) consists of two testes and each testis consists of a series of slender follicles (Viscuso \& Vitale, 2015). 

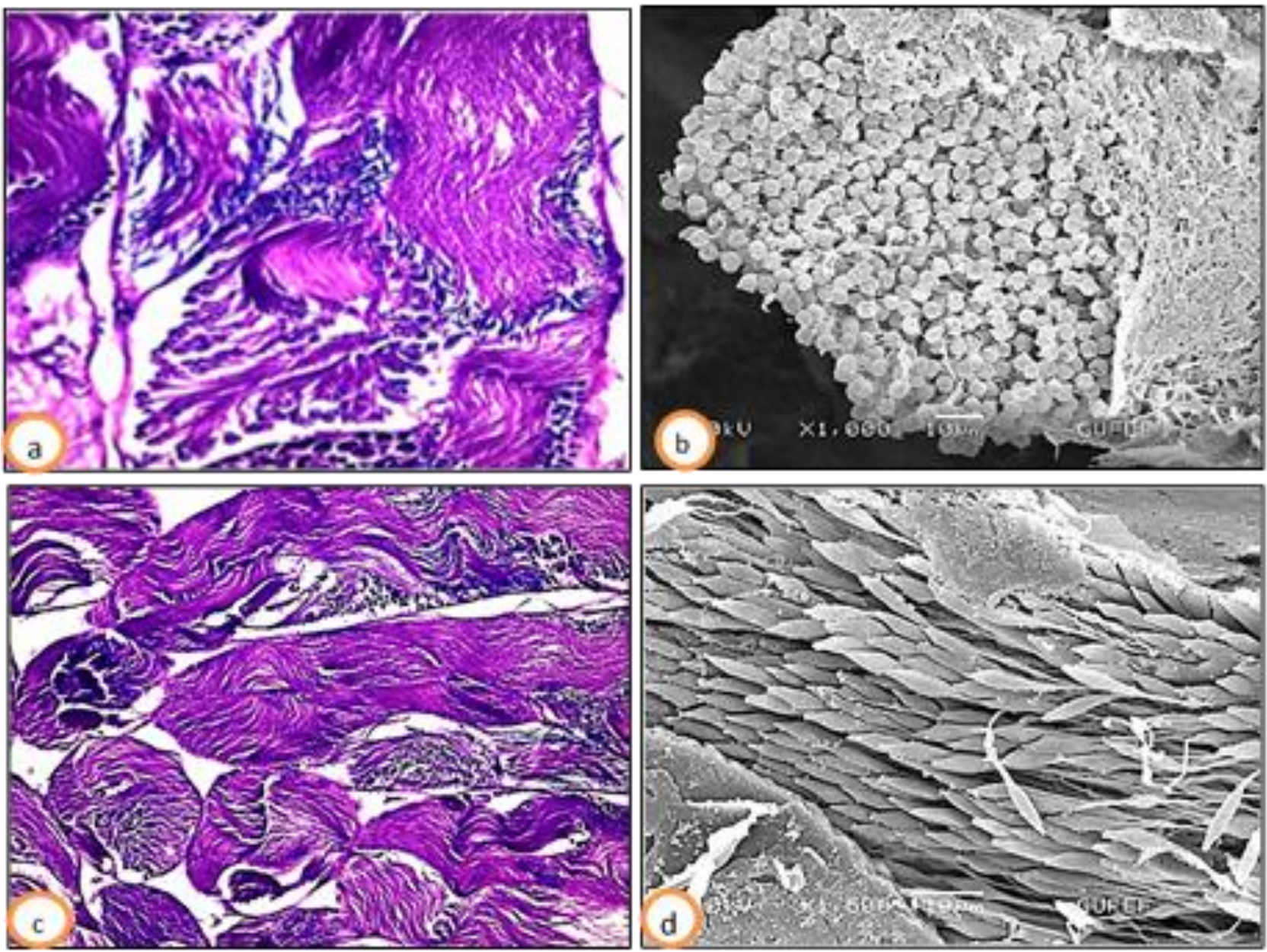

Figure 5. The spermatids and spermatozoa in differentiation zone. a. Differantation of spermatids to spermatozoa in testicular folicle (x400) (H\&E) (LM). b. The round head regions in the spermatids (SEM). c. The histological section of spermatozoa in regular bundles shaped (x400) (H\&E) (LM). d.The spermatozoon head and flagellum parts (SEM).

Male reproductive system of $G$. campestris consist of a couple of testes and every testis is comprised of 140 testicular tubules. In G. assimilis (Orthotera: Gryllidae) each testis is comprised approximalety 280 follicles. The follicles are slightly spindle- shaped. In Gryllodes sigillatus (Walker) (Orthoptera: Gryllidae) every testis is occurig approximalety 154 follicles (Nandchahal, 1972). In Tylopsis liliifolia (Orthoptera: Tettigoniidae) either testis is formed of 30 to 39 separate testicular follicles.

Additionally, every testicular follicle has a characteristic teardrop shape. There is little change in the shape between the follicles (Viscuso \& Vitale, 2015). However, Parrettix toltecus (Orthoptera: Tetrigidae) consists of 9 follicles and Tetrix vittatum Zett. Consists of 30 follicles each testes (Widdows \& Wick, 1959). Male reproductive system of Baeacris punctulatus (Orthoptera: Acrididae) consists of two testes and each testis has 30 follicles (Michel \& Teran, 2005). In Orphulella punctata (Orthoptera: Acrididae) each testis consists of 4 follicles and their structure is filiform. (Silva et al., 2018). The number of testicular follicles varies by species. e.g. Chortophaga viridifasciata (Orthoptera, Acrididae) 26-28, Melanoplus differentialis (Orthoptera, Acrididae) 188 and Romalea microptera (Orthoptera, Romaleidae) (Silva et al., 2018).

In the male reproductive system of $G$. campestris every testis is consist of many testis follicles in which varied stage of spermatogenesis (spermatocytes, spermatids, and spermatozoa). The structure and arrangement of the sperm is generally the sperm of other locusts. It is similar to its structure. Initially, the germ cells at the proximal end of the testicular follicle undergo mitosis to form spermatocytes. Later, spermatids are formed from the spermatocytes in the middle region of the follicles through meiosis. At last, spermatids, in the proximal region of the follicle differentiation into spermatozoa. Similar developments have been seen in $O$. punctata (Orthoptera, Acrididae), Pseudochorthippus parallelus parallelus (Orthoptera, Acrididae), P. cervus (Orthoptera, Tettigoniidae) (Polat, 2016; Silva et al., 2018; Polat et al., 2019). At the end of the differentiation stage, to form bundles of sperm, a large number of sperms comes together. Orphulella punctata showed 450 spermatozoa per bundle and for Orthoptera, the presence of sperm in bundles occurs in Eumastacidae and Acrididae with number of sperm per bundles range from 256 to 2048 (White, 1954; Silva et al., 2018).

Vas deferens of G. campestris is quite long and thin. Vas deferens connects the testicles to the ejaculatory canal. Vas deferens connects testes to the ejaculatory duct in the male reproductive system of $P$. parallelus parallelus too. It is a long thin canal originating from the middle part of the testis in vas deferens, $P$. Parallelus parallelus, $P$. cervus, and G. sigillatus. (Nandchahal, 1972; Polat, 2016; Vitale et al., 
2011; Viscuso \& Vitale, 2015). Accessory glands are a part of the male reproductive system, differ in shape and number. Although, they are quite similar histologically. In G. campestris, the accessory glands are on both sides of the ejaculatory duct and they seem to be many of white tubules. In Locusta migratoria migratorioides, the accessory glands are on either sides of the ejaculatory duct (Gallois \& Cassier, 1991, Polat et al., 2020). Accessory glands in G. sigillatus, consists of six groups of tubules of various colors and sizes. (Nandchahal, 1972).
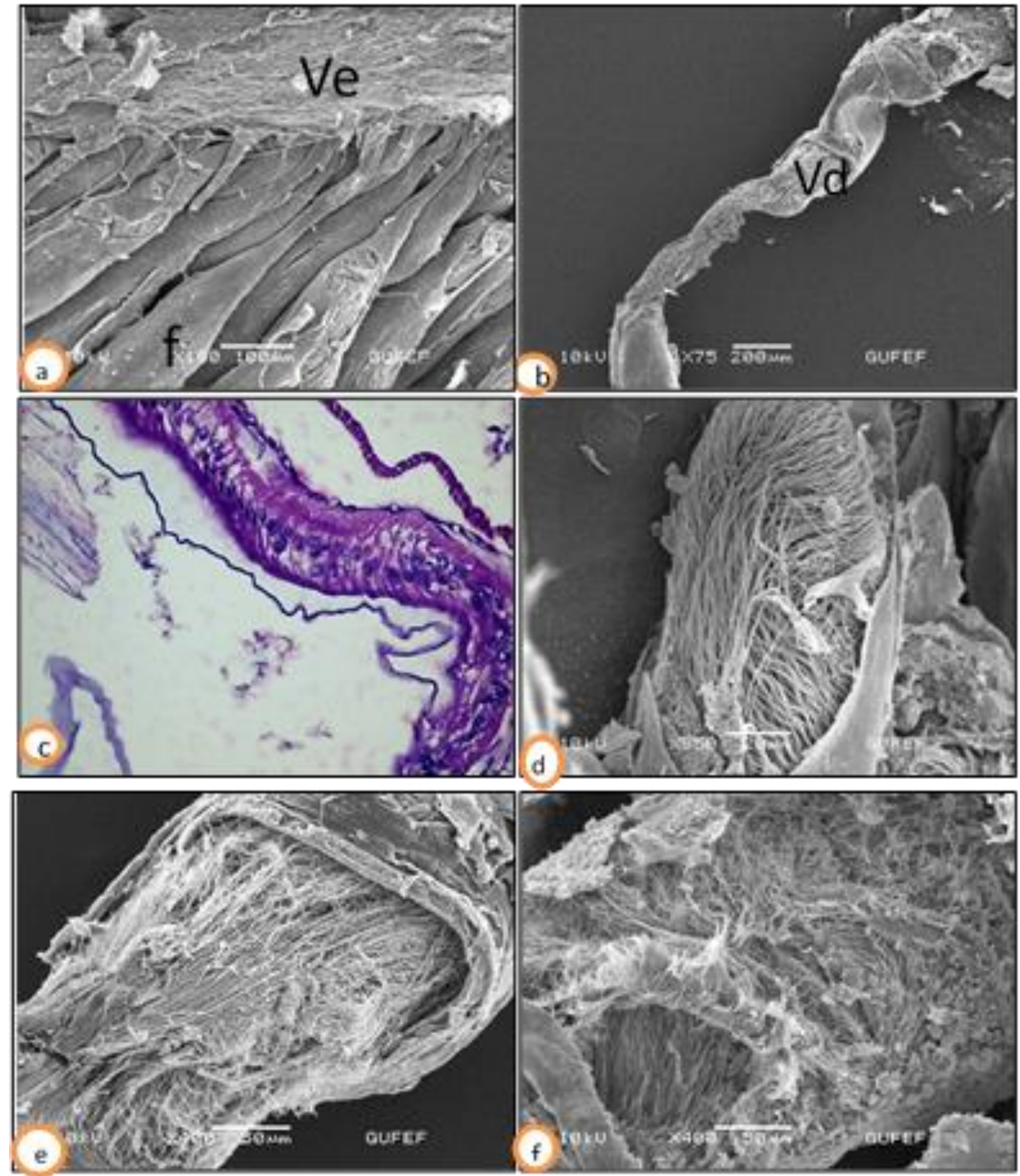

Figure 6. The vas deferens in G. campestris. a. The connection of testicular follicles to the vas deferens (Vd) by the vas efferentia (Ve) (SEM). b. The sperm tails in stack in the vas deferens lumen (SEM). c. The muscle layer and mono layered epithelium with oval nucleus surrounding the vas deferens (x1000) (H\&E) (LM). d-f. The mature sperm bundles in the lumen of vas deferens (SEM).

In Locusta migratoria, Gomphocerus rufus, S. gregaria and Camnula pellucida consist of 16 tubules but $P$. parallelus parallelus consists of 10 tubles (Kaulenas, 2012; Chapman, 2013; Polat et al., 2020). Even so Gryllus sp. (Orthoptera, Gryllidae) consists of approximately 600 tubles (Chapman,
2013). Accessory glands of G. campestris have no cuticle layer on the wall. Accessory glands produced secretions formed plays a role in the production of spermatophore and transfer of sperm to female individual (Chapman, 2013). 

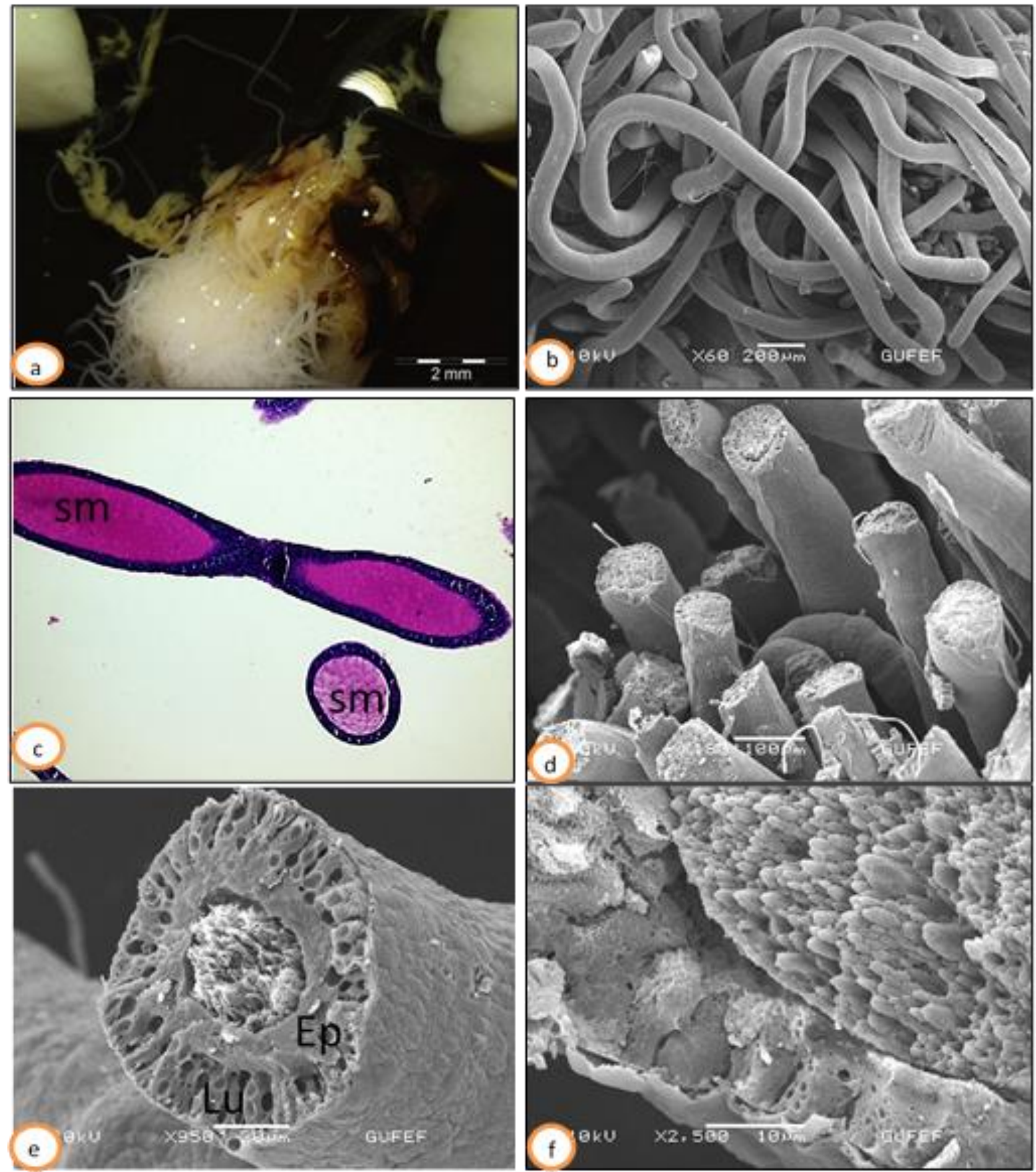

Figure 7. The accessory glands in G. campestris. a. The general view of white, thin, long and complex accessory glands (SM). b. The accessory glands with smooth surface (SEM). c. The longitudinal and cross section of accessory gland (x200) (H\&E) (LM). d-f. A single layer of epithelium surrounding the accessory glands and lumen filled with secretory material (Sm) (SEM). Ep-epithelium, Lu-lumen, Sm-secretion material.

Male reproductive system of G. campestris has of a spermatophore which was fixed at the level of the female gonophore. The spermatophore is flask-shaped with a wider part called ampulla with a neck and attachment plate and with a long sperm tube. The sperm sac nearly similies a pear which is white and contained the mixed up spermatodesms and a dense yellowish secretion.

In Decticus verrucivorus (Orthoptera: Tettigoniidae), spermatophore is connected externally to the female's genitalia and occurs of two parts: a large, gelatinous, sperm-free portion, the spermatophylax, used as food by the female after mating; and a sperm-containing ampulla, eaten after the spermatophylax has been eaten (Wedell \& Arak, 1989). In the species examined (Orthoptera: Tettigoniidae), the spermathopore have a similar morphology. They were flask-shaped, with a wider part called ampulla, with a long peduncule or neck. Spermatophore of T. Liliifolia, the sac is opalescent white 
and contained the mixed up spermatodesm and a dense, colourless secretion but Bolivarius siculus has yellowish secretion (Viscuso et al., 2015) Spermatophore of Gryllus bimaculatus (Orthoptera: Gryllidae) occurs of an ampulla (containing the spermatozoa), a long slender sperm tube and an attachment plate (Hall et al., 2000).

Consequently, the purpose of this article is to contribute to explaining the male reproductive system of G. campestris, providing biological control against this species and revealing properties that may be useful for future studies on the taxonomy and phylogeny of other Orthoptera species.

Ethics committee approval: Ethics committee approval is not required for this study.

Conflict of interest: The authors declares that there is no conflict of interest.

\section{References}

Chapman, R.F. (2013). Alimentary canal digestion and absorption. In S. J. Simpson and A. E. Dougles (Eds). The insect structure and function. Cambridge: Cambridge University Press, 46-80.

Çıplak, B., \& Demirsoy, A. (1996). Caelifera (Orthoptera: Insecta) alttakımının Türkiye'deki endemizm durumu. Turkish Journal of Zoology, 20(3), 241-246.

Çıplak, B., Demirsoy, A., Yalım, B., \& Sevgili, H. (2002). Türkiye Orthoptera (=düzkanatlılar=çekirgeler) faunası. A. Demirsoy (Editör). Genel zoocoğrafya ve Türkiye zoocoğrafyast: Hayvan coğrafyası. (Beşinci Baskı). Ankara. Meteksan A.S.., s. 681-707.

Demirsoy, A., Salman, S., \& Sevgili, H. (2002). Novadrymadusa, a new genus of bushcricket with a new species and notes on related genera (Orthoptera: Tettigoniidae). Journal of Orthoptera Research, 11, 175-183. http://doi.org/10.1665/1082-6467(2002)011[0175:NANGOB]2.0.CO;2

Gallois, D., \& Cassier, P. (1991). Cytodifferentiation and maturation in the male accessory glands of Locusta migratoria migratorioides (R. and F.) (Orthoptera: Acrididae). International Journal of Insect Morphology and Embryology, 20(3), 141-155. https://doi.org/10.1016/00207322(91)90005-T

Gullan, P.J., \& Cranston, P.S. (2010). The insects: an outline of entomology, 4th Edition, Wiley-Blackwell Publishing, $565 \mathrm{pp}$

Hall, M.D., Beck, R., \& Greenwood, M. (2000). Detailed developmental morphology of the spermatophore of the Mediterranean field cricket, Gryllus bimaculatus (De Geer) (Orthoptera: Gryllidae). Arthropod Structure \& Development, 29(1), 23-32. https://doi.org/10.1016/S1467$\underline{8039(00) 00010-4}$

Jones, N., Taub-Montemayor, T., \& Rankin, M.A. (2013). Fluoresceindextran sequestration in the reproductive tract of the migratory grasshopper Melanoplus sanguinipes (Orthoptera, Acridiidae). Micron, 46, 80-84. https:// doi.org/10.1016/j.micron.2012.12.003

Kaulenas, M.S. (2012). Insect accessory reproductive structures: function, structure, and development. New York, Springer Science \& Business Media, $223 \mathrm{pp}$

Liu, X, Zhang, J., Ma, E., \& Guo, Y. (2005). Studies on the phylogenetic relationship of acridoidea based on the male follicle morphology (Orthoptera: Acridoidea). Oriental Insects, 39, 21-32. https://doi.org/10.1080/00305316.2005.10417415

Harz, K. (1969). Die Orthopteren Europas I The Hague:.1. Series Entomologica,5, The Hague (Dr. W. Junk N.V.), 749 pp.
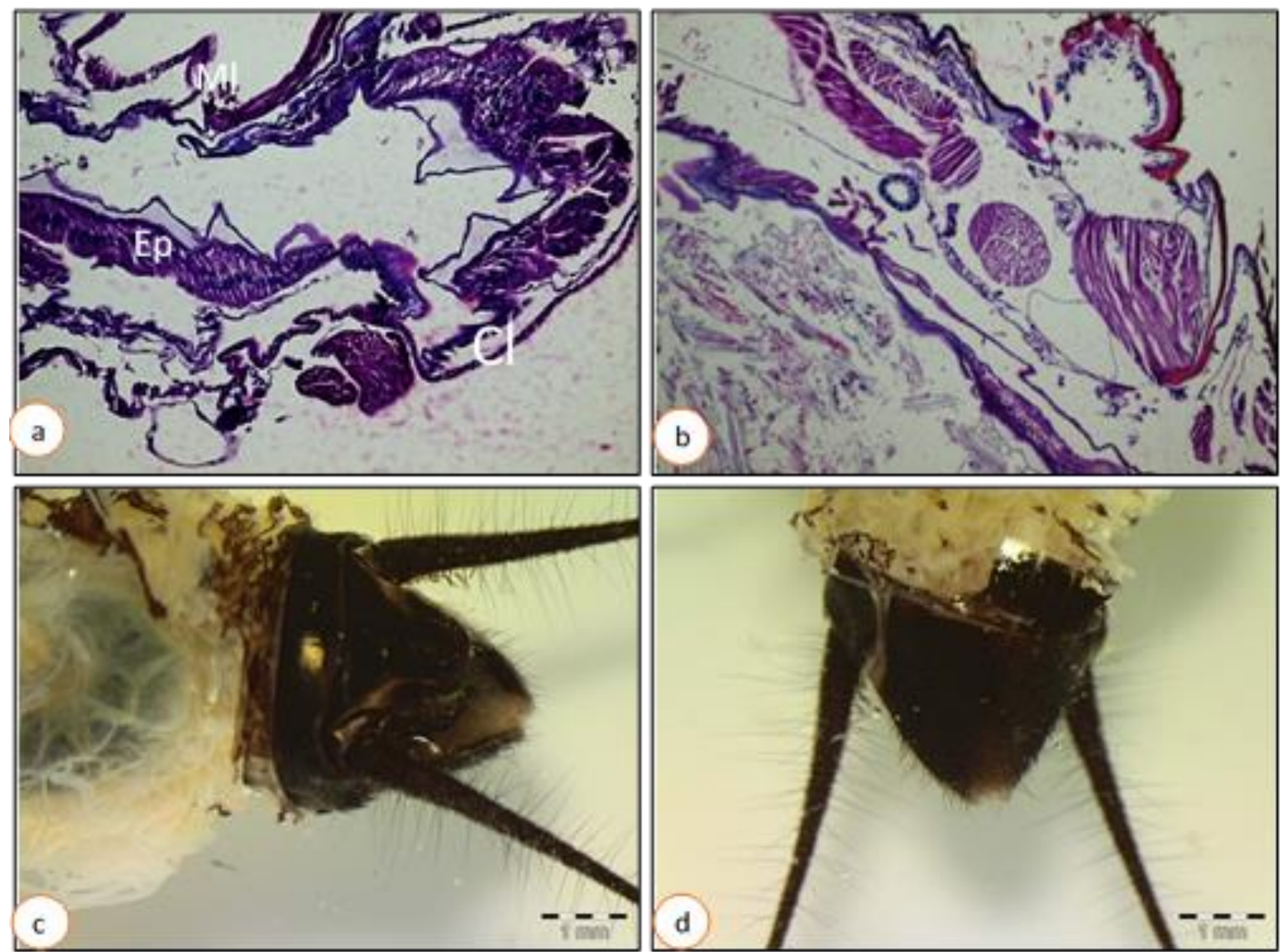

Figure 8. The ejaculator canal and genital chamber of G. campestris. a. The cuticular layer (Cl), a single layer cylindrical epithelial (Ep) and muscle layer $(\mathrm{Ml})$ surrounding ejaculatory duct $(\mathrm{x} 400)(\mathrm{H} \& \mathrm{E})(\mathrm{LM})$. b. The histological section of muscle bundles between ejaculatory duct and genital chamber (x400) (H\&E) (LM). c, d. The general view of male genital of G. campestris (SM). 

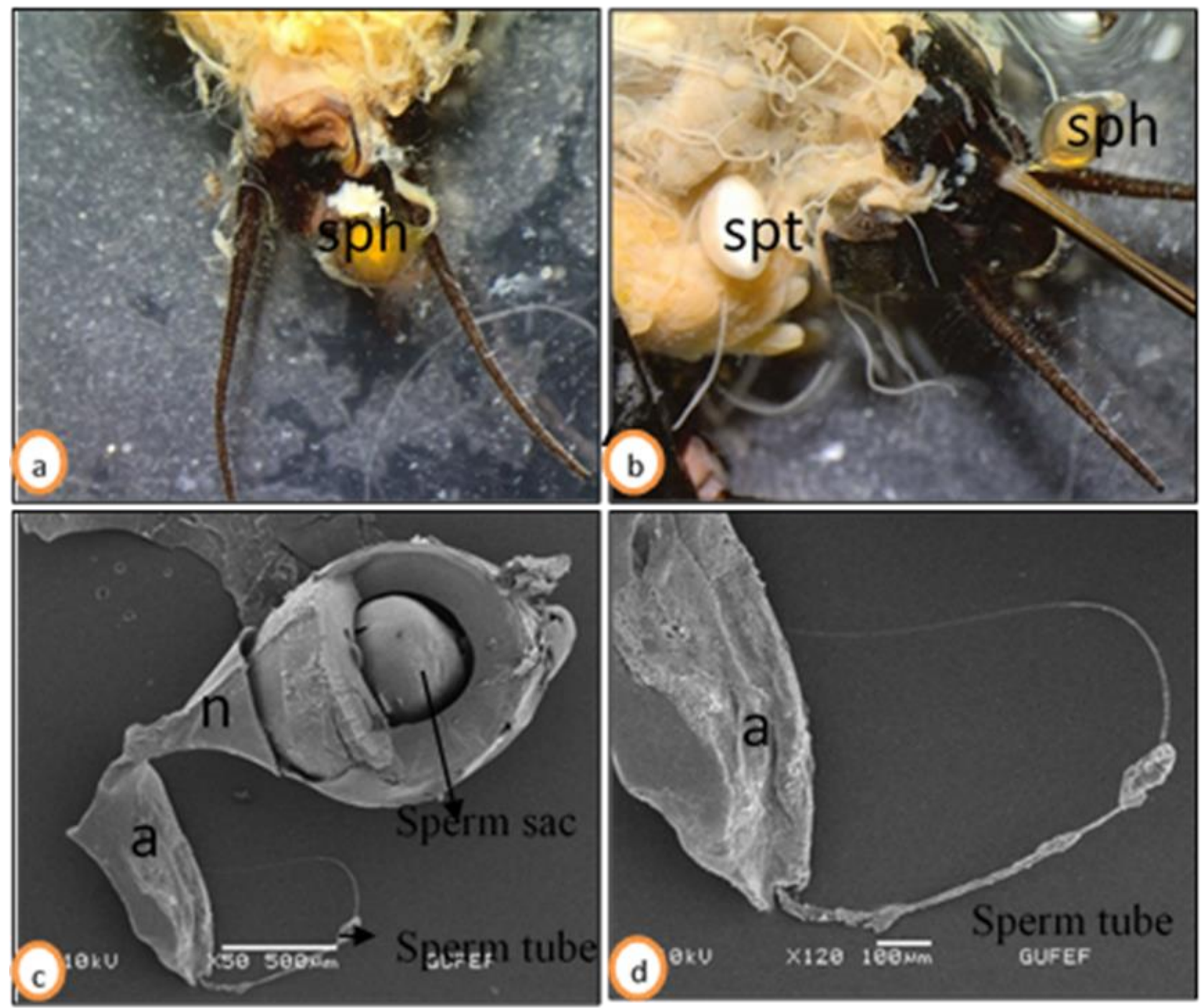

Figure 9. The spermatheca (spt) and spermatophore (sph) in G. campestris. a. The general view of spermatophore in male. b. The general view of spermatophore and ovipositor in female (SM). c-d. The sperm sac. $d$ The neck (n), attachment plate (a) and spermtube (SEM).

Marchini, D., Brundo, M.V., Sottile, L., \& Viscuso, R. (2009). Structure of male accessory glands of Bolivarus siculus (Fischer) (Orthoptera, Tettigoniidae) and protein analysis of their secretions. Journal of Morphology, 270, 880-891. https://doi.org/10.1002/jmor.10727

Michel, A., \& Terán, H.R. (2005). Morphological analysis of the female reproductive system in Baeacris punctulatus (Orthoptera, Acrididae, Melanoplinae). Revista de la Sociedad Entomológica Argentina, 64(3), 107117

Nandchahal, N. (1972). Reproductive organs of Gryllodes sigillatus (Walker) (Orthoptera: Gryllidae). Journal of Natural History, 6, 125-131. https://doi.org/10.1080/00222937200770111

Otte, D., \& Cade, W. (1984). African crickets (Gryllidae). 6. The genus Gryllus and some related genera (Gryllinae, Gryllini). Proceedings of the Academy of Natural Sciences of Philadelphia, Philadelphia, 136, 98-122.

Polat, I. (2016). Poecilimon cerous Karabag, 1950'un Sindirim, Boşaltim, Dişi ve Erkek Üreme Sisteminin Ultrastrüktürel Özellikleri (441895) Retrieved from https://tez.yok.gov.tr/UlusalTezMerkezi/giris.jsp

Polat, I., Amutkan Mutlu, D., Unal, M., \& Suludere, Z. (2019). Histology and ultrastructure of the testis and vas deferens in Pseudochorthippus paralleus parallelus (Orthoptera: Acrididae). Microscopy Research Technique, 82(9), 1461-1470. https:// doi.org/10.1002/jemt.23300

Polat, I, Amutkan Mutlu, D., \& Suludere, Z. (2020). Accessory glands of male reproductive system in Pseudochorthippus paralleus parallelus (Zetterstedt, 1821) (Orthoptera: Acrididae): A light electron microscopic study. Microscopy Research Technique, 1-7. https://doi.org/10.1002/jemt.23406

Snodgrass, R.E. (1937). The male genitalia of orthopteroid insects. Smithsonian miscellaneous collections. Washington: Smithsonian Institution, 96(5), 1-107.
Snodgrass, R.E. (1957). A revised interpretation of the external reproductive organs of male insects. Smithsonian miscellaneous collections, 136 (6), 1-60.

Silva, D.S.M., Cossolin, J.F.S., Pereira, M.R., Lino - Neto, J., Sperber, C.F., \& Serrao, J.E. (2018). Male reproductive tract and spermatozoa ultrastructure in the grasshopper Orphulella punctata (De Geer, 1773) (Insecta, Orthoptera, Caelifera). Microscopy Research and Technique, 81(2), 250-255. https://doi.org/10.1002/jemt.22973

Viscuso, R., \& Vitale, D.G.M. (2015). Spermatodesm reorganization in the spermatophore and in the spermatheca of the bushcricket Tylopsis liliifolia (Fabricius) (Orthoptera, Tettigoniidae). Arthropod Structure and Development, 44, 243-252. https://doi.org/10.1016/j.asd.2015.03.004

Viscuso, R., Brundo, M.V., Marletta, A., \& Vitale, D.G.M. (2014). Fine structure of male genital tracts of some Acrididae and Tettigoniidae (Insect: Orthoptera). Acta Zoologica, 96, 418-427. https://doi.org/10.1111/azo.12084

Viscuso, R., Narcisi, L., \& Sottile, L. (1999). Structure and function of seminal vesicles of Orthoptera Tettigonioidea. International Journal of Insect Morphology and Embryology, 28, 169-178. https://doi.org/10.1016/S0020-7322(99)00022-7

Vitale, D.G.M., Brundo, M.V., \& Viscuso, R. (2011). Morphological and ultrastructural organization of the male genital apparatus of some Aphididae (Insecta, Homoptera). Tissue and Cell, 43, 271-282. https://doi.org/10.1016/j.tice.2011.05.002

Vrenozi, B, \& Uchman, A. (2020). Burrows of the common field-cricket Gryllus campestris Linnaeus, 1758 (Orthoptera: Gryllidae) from Dajti Mountain, An International Journal for Plant and Animal Traces, Albania, 28(1), 46-55. https:/ / doi.org/10.1080/10420940.2020.1843455

Wedell, N., \& Arak, A. (1959). The wartbiter spermatophore and its effect on female reproductive output (Orthoptera: Tettigoniidae, Decticus 
verrucivorus. Behavioral Ecology and Sociobiology, 24, 117-125. http://doi.org/10.1007/BF00299643

Widdows, R.E. \& Wick, J.R. (1959). Morphology of the reproductive system of Tetrix arenosa angusta (Hancock) (Orthoptera: Tetrigidae). Proceedings of the Iowa Academy of Science, 66(1), 484-503.

White, M.J.D. (1954). Patterns of spermatogenesis in grasshoppers. Australian Journal of Zoology, 3, 222-226. https://doi.org/10.1071/ZO9550222 